Ю.В.Василенко,

аспірант кафедри історії філософії

КНУ імені Тараса Шевченка

\title{
ПЕРЕРВНІСТЬ ПРОСТОРУ СВІТОВИХ ЯВИЩ ЯК МОЖЛИВІСТЬ ПОВЕРНЕННЯ ДО СВІТЛА ВІЧНОСТІ
}

Відчуття включеності людського єства (в усіх його проявах) до просторовості світу виникає щоразу, коли відбувається відсторонення глибин душі від світової поверхні, наповненої площинними одновимірними схемами, серед яких втрачаються орієнтири. Звичним для мешканців цієї світобудови є сприйняття лінійних векторів руху, якими можна пересуватися без «зайвого навантаження» аж до краю останнього горизонту, що постає перед закритими очима. Бути «запущеним» 3 однієї точки початку руху аж до самого «кінця історії» - чим не ідеальний спосіб погратися у власне життя? Таке «лінійно-ліниве» сприйняття щомиттєвого «відбування» світу призвичаїло нас до безтурботної вмонтованості в переконання про те, що весь простір є тотально неперервним, цілковито самодостатнім та абсолютним. Це, своєю чергою, призводить до «онтологічної байдужості» тих, хто в ньому перебуває. А байдужість така полягає в тому, що жодних «виходів назовні» шукати не потрібно. Однак на зміну такому світовідчуттю своєчасно виринула 3 глибин віковічної пам'яті людства давно забута картина світу перервного. Перший поштовх до таких перемін дав математик Георг Кантор, якому належало відкриття теорії множин. Згодом його ідеї лягли в основу розробок представників Московської філософсько-математичної школи, зокрема Миколи Васильовича Бугаєва. Найбільш своєрідної інтерпретації ідея перервності набрала в творчості чи не найбільш загадкового російського філософа, богослова та математика Павла Олександровича Флоренського. Спробуємо розглянути головні «смислові осередки» його глибинних інтуїцій.

В найглибших основах людського сприйняття криється відпочаткове прагнення до цілісності, що може проявлятися як схоплення в єдиному потоці всіх життєвих процесів. Так, саме життя, коли кидаємо загальний погляд свідомості-душі на нього, постає немовби єдиним здійсненням. Але від народження до смерті триває час, 
період нашого перебування в земних координатах. У цьому часі проходимо відстані, які, своєю чергою, складаються з етапів, моментів проживання, точок на паралельних прямих наших душ, що перетинаються у викривленому просторі всесвіту. Намагаючись проігнорувати вирішальність кожного такого моменту очікуваної єдності, ми втрачаємо пам'ять про іiі надсвітові джерела. Затуманюються ті траєкторії мислення, які мали б виводити його до меж звільнення, до тієї сфери, з якої беруть свій виток геніальні осявання, що заповнюють смисловий вакуум між свідомостями, між полюсами сприйняття. Тому й постає для неї абсолютною та нескінченно-незнищенною матерія видимого світу. Однак все лишається насправді, в глибині своєї природи тільки позірністю, своєрідною оманою духовного зору. П.О.Флоренський пропонує принаймні спробувати взяти за фундуючий принцип світобудови принцип перервності, який розкриває основну ідею аритмології М.В.Бугаєва та відсилає нас ще далі, в глиб тисячоліть, до надраціональної мудрості людства та до піфагореїзму зокрема. Думка про те, що всьому у світі закладено свою міру, суголосна з піфагорійським «все $\epsilon$ число», що спонукає до вбачання у світі не тотальності та єдиновимірності, а різнорідності, багатомірності простору, в якому кожній речі $є$ «своє місце під сонцем», а отже, є своє власне унікальне призначення. «Простір складний, нелінійний, дискретний, різні місця його мають різну смислову напругу» $[1,20-21]$. За такого взорування на дійсність втрачається двомірне іiі сприйняття (тільки зовнішньовнутрішне). А натомість всі зовнішні видозміни постають виразниками тих процесів, які мають місце у світі внутрішньому. Адже «смислова напруга» кожного умісцевленого явища бере свій виток iз траєкторій розгортання його прихованої до певного часу сутності.

Згідно з принципом перервності, що є полюсом інакшості, до аналітичного (неперервного) світоспоглядання кожне явище постає перервним, а отже, - кінечним в будь-яких межах часу та простору. Що насамперед може випливати із даного постулату? Флоренський вважав, що первинним його наслідком є безглуздість пошуку абсолюту, абсолютної істини посеред світових обмеженостей. Ніде в світі не існує однозначної відповіді на питання про смисл усього створеного. Тож душею своєю людина мусить підноситися до Бога, Творця усього «видимого та невидимого», бо тільки в Ньому може віднайти первозданний спокій. 
Ще одним наслідком принципу перервності $є$ неможливість схопити та пізнати ціле в його елементарних поодиноких проявах. Ціле завжди виявиться нескінченно більшим за свої частини. Це також є свідченням того, що кожна видима річ-явище завжди постає більшою і за саму себе, бо видимість ії - тільки наслідок проростання із глибин незбагненного, з «таємниці, в якій життя світу», за словами Флоренського. 3 такого підходу цілком очевидним виявляється також змінність законів кожної речі-як-відокремленості та неможливість кожного опису того чи іншого явища для минулих та майбутніх моментів часу. Світовий візерунок невпинно змінює свої орнаменти, посеред яких нічого не можна передбачити, окрім лише ймовірності того чи іншого виникнення чи зникнення. Якщо ж минуле та майбутнє лишаються за межею достовірного сприйняття, нам лишається тільки миттєвість теперішнього, в якій маємо робити одвічний вибір між Небесами та темрявою. I саме перервність світових явищ стає умовою можливості такого вибору, який не можна не зробити. Неможливість покластися на жодну річ у світі так чи інакше спонукає людину плекати в собі «прагнення просуватися по вертикалі та малу зацікавленість у горизонталі» [2, 99]. Світові горизонталі завжди непомітно спонукають до нескінченності, до горизонту, який постійно віддаляється, бо є виключно ілюзієї людського розсудку, в яку вірять людські очі. Тому така нескінченність - це завжди рух замкненим колом, а тому - теж лише ілюзія руху. І тільки устремління душі «по вертикалі» здатне вивести іiі із коловерті світових перемін до незмінності Божого світу.

Згідно з теорією Георга Кантора, континуум є зв'язаною та довершеною множиною точок, а тому, «якщо простір має реальне буття, то йому немає потреби бути неперервним» [3, 215]. Строката сукупність таких точок-явищ з причини їх незліченної кількості створює позірність вічності та нескінченності, але насправді кожна точка відокремлена від іншої «вакуумом», який слугує збереженню унікальної смислової напруги для кожної з них. «Просторові образи перервні, і лише вкрай спеціальні умови привносять в них той комплекс ознак, за які ми маємо право називати ці образи неперервними» [3 77]. Відтак позірність неперервності є лише ймовірним випадком в межах перервності. Однак існує неперервність, безвідносна щодо всього створеного світу. Вона існувала в первозданому космосі до гріхопадіння. Спробуємо відшукати її витоки. 
«Вроджена» потреба в нескінченності, попри ув'язнену в гріх душу, заломлюється в поцейбіччі, але не через призму світла, а через призму закам'янілої свідомості, яка забуває про можливість творчості в кожному своєму прояві і, почувши бодай одну «плітку» сплячого світу, не намагається іiі хоча б якось видозмінити, натомість прокручує застарілий сценарій в уяві свого носія. Перебувати в саморобній вічності - чим не рай для втомлених мандрівників, котрі ладні погодитися хоча б на якийсь прилисток? Але величезна пастка криється в тому, що «ніби-рай»є завжди насправді «антираєм». I підміна така перебуває в самій глибині нашого сприйняття, забарвлюючи в свої тьмяні кольори кожну новонароджену думку. А думки й собі породжують дії; останні ж випромінюються в світ, впливаючи на його долю.

Звеличуючи штучну цілісність посеред перервного світу, ми цілком «законно» випадаємо з простору цілісності справжньої, бо втрачаються задані орієнтири, за якими варто було б спрямовувати життя. Але навіть за таких умов справжня цілісність ніяк не втрачає своїх «повноважень». У цьому ключі передбачливими та глибинними здаються слова Франца Кафки: «Ми були вигнані $з$ раю, але він не був зруйнованим. Вигнання з раю було в якомусь смислі щастям, адже, якщо ми не були б вигнані, рай довелося б знищити» $[4,59]$. Унікальність такого погляду дивовижним чином постає абсолютно суголосною з ідеями аритмології та іï розгортанням у філософії Павла Флоренського. Вигнання з раю - неуникний наслідок гріхопадіння, після якого ми добровільно опинилися в розколеному - перервному - світі. Але навіть після такого занурення людей у прірву уявної та мертвої самодостатності Божий задум про світ не припиняє існувати. Гріх та рай є несумісними. Істинне життя в Богові $є$ фактично перешкодою для подальшого розгортання гріховності в людській душі. А тому їм - людині та раю довелося стати розділеними. Однак останній на всі часи лишається незмінним до останнього згортання небес. А тому істинна нескінченність і є тим Божим світом, досягти якого можна, тільки змушуючи свою душу рухатися вертикальним вектором.

Перервність та неперервність є двома полюсами нашого потойбічного для раю світу. Саме наш світ $є$ потойбіччям, бо істинна реальність істинної нескінченності - завжди безвідносна до умісцевленостей. «Де виявляється перервність, там ми шукаємо цілого; 
а де $\epsilon$ ціле - там діє форма i, як наслідок, існує індивідуальна обмеженість дійсності від навколишнього середовища» [5, 63]. Така картина світу дає змогу побачити навіть посеред розколеності умови можливості до повернення в сферу істинного. Бо навіть у розірваному хибою-брехнею світу кожне явище $\epsilon$ вкоріненим у природу райського світу. Покрови речей не приховують їх сутності, а, навпаки, покликані їх розкривати за участю очищеної душі, що діє впевнено. Явлені речі виток свій беруть у світі ідей i, виникаючи по цей бік світла істини, вони приносять сюди його відблиски. Тому ми можемо говорити про оформленість кожного явища в сенсі його готовності являти щось більше, ніж власну видимість. Флоренський визначає форму саме як те ціле, що більше всіх своїх частин. Це, своєю чергою, є свідченням того, що цілісність всього, яка існувала до світового розколу, все ж лишається невидимо присутньою і після нього. «Прийняття форми невіддільне від прийняття перервності і тільки прийняття і того й іншого спричинює осягнення істинної єдності живої цілісності» $[6,177]$. В цих словах висловлюється розуміння того, що визнання однієї розколеності-перервності світу не має жодного смислу, оскільки не здатне призвести людське єство до вирішальної точки вибору істинної дії в такому світі. Необхідним є ще один компонент для обрання достеменного напряму руху. Таким компонентом і постає поняття форми як напередзаданої цілісності посеред безцільного проживання життя. За цю ідею варто тільки вхопитися, і вочевидь необхідними стануть всі перешкоди та прірви посеред світу.

Без такого розуміння крапля води ніколи не зможе стати «посланцем» океану, але ж і сам океан нам не розпізнати, доки не вдасться розпізнати природу води, що пронизує собою кожну його краплю. Через такі духовні лінощі «особистість розсипається, стверджуючи відсторонену єдність всієї своєї діяльності. Але це не соборність, не синтез, не творче об'єднання, а механічна суміш розклад, словом, не життя, а смерть. І смерть - не від злої волі того чи іншого діяча культури, а необхідний наслідок самого ії ходу» $[7,371]$. У цьому ми вбачаємо розкриття механізму переходу «на зворотний бік» справжнього шляху. Чим далі від смислового центру життя - Бога - розходяться напрямки глибинної діяльності людського єства, тим строкатішими, але пустотнішими стають іiі прояви. Розпорошення на нескінченність дріб'язкових фрагментів думок- 
відчуттів все далі відсторонює погляд людської душі від іï істинного вигляду. У наведених словах о. Павла Флоренського просвічується сама квінтесенція такого віддалення. Адже там, де відсутнім є об’єднуюче осердя, навколо якого мали б збиратися всі реальності, не просто неможлива істинна єдність, а виникає іï «замінник» iз протилежним значенням - «механічна суміш», яка $\epsilon$ не чим іншим, як передумовою забуття світла, духовного тління.

Бажання роздрібнити ціле на частини 3 подальшою абсолютизацією цих частин є наслідком невиправданої «гри в піжмурки» 3 власним істинним єством. Адже світ давно розколотий сам у собі через прагнення «вінця творіння» жити на власний розсуд, забувши Бога та роблячи вигляд, що немає над землею неба. Однак навіть така розколеність повернена Божою благодаттю на добро, оскільки в ті рани-розломи нашого стражденного світу здатне пролитися світло вічності та зцілити його відокремленість від себе. «Якщо організм є метафізичною формою, а не периферією тіла, то форма пронизує всяку частку; а оскільки форма є індивідуальною, то всяка частка виявляється індивідуальною та особистісною... Оскільки саме форма і є реальністю, то додавання елементів є тільки умовою, за якої вона могла б проявитися» [8, 349]. Відтак наявність визнання заданої, дарованої форми як втілення ідеї-образу в координатах простору та часу уможливлює присутність смислу в кожному фрагменті дійсності. I навпаки, відсутність такого розуміння як фундаменту мислення та здійснення життя призводить до зворотних процесів. Елементи-уламки, втрачаючи свій витоковий зв'язок із верховним задумом про світ, прагнуть виокремити та абсолютизувати світ у самих собі. Однак це прирівнюється до творення реальностей там, де навіть немає місць для осідання пилу, оскільки духовна пустка завжди є причиною пустки «матеріальної», видимої. Але єдність первинного джерела здатна пролитися в світ розпорошених реальностей відкритістю своїх істин. Однак з пилу часу може прорости «живе життя» тільки в разі розпізнання пилом власного не-існування. Розколи потрібні для того, щоб мертва пустотність не була замкнена на самій собі, а просвічувалася б світлом нетутешності. Бо кожен найменший світловий спалах дає повне знання про природу світла, хоча і в мінімальному його «просторовому» проявленні. Тому кожен вияв такого осмислення постає не лише видимістю небесних основ життя, а й уособлює собою повний його 
образ. «У світі володарює перервність щодо зв’язків та дискретність щодо самої реальності... Дискретність реальності приводить до ствердження форми або ідеї (в платоново-арістотелівському смислі) як єдиного цілого, яке «випереджає свої частин» та їх собою визначає, а не 3 них складається. Звідси - ...прагнення зрозуміти число як форму» $[9,41]$. Сама роздільність простору світових явищ спонукає «духовно зосереджену» душу віднаходити єдиний образ цілого в уламках розбитих дзеркал реальності. Образ Божий, котрий закладений в кожному, мусить бути розчищеним від тисячолітніх нашарувань гріховності через покаяння, яке одне тільки й здатне вивести наш дім-світ 3 полону ілюзорних перебувань. Флоренський, як православний богослов, надає можливість угледіти давньогрецькі ідеї у світлі християнства, в якому, на його думку, і здійснюється та омріяна всеєдність, що охоплює всі прояви та рівні людського здійснення.

Відчуття того, що світ є надтріснутим, надає можливість «заповнити» ці тріщини «лазурним світлом вічності». Якби таких розколів не існувало, то світ земний цілком перетворився б на світ пекельний, в буквальному розумінні цього слова, в сенсі неможливості проникнення в нього істинної любові, яка «не від світу цього». Нескінченний час та простір - то немовби глибокий, але пустий та тривожний сон, із якого неможливо пробудитися. Насправді нескінченність в цьому світі є страшною оманою, повіривши в яку, можна навічно потрапити до іiї полону. Бо сутністю такої «нескінченності» завжди є тільки не-реальність, відсутність реальності, а отже, відсутність життя, що є Божим даром.

Обмеженість смислу та просторова тиснява суперечать самій людській природі, бо все створене є «символом Нескінченного, символом Безкрайнього: кожне створіння завершується нескінченністю, кожне скінченне однією своєю гранню вступає в нескінченність. Не існує нічого скінченного, нічого властиво свого, але все $\epsilon$ таємничим та нескінченним... Все створене вимовляє якусь Божу таємницю, таємницю Слова» [10, 149]. Проникнення містичних коренів духу в глибини такого усвідомлення видозмінює весь людський спосіб буття. Повернення до світла вічності має бути здійсненим у «нинішньому» розколеному просторі, що потребує преображення. А останнє можливе за умови очищення його від штучної абсолютизації, визнання його зараженості людськими ілюзіями. Сдність - завжди за межами будь-якої змертвілої думки про неї, 
вона відбувається як глибинне ії переживання-проживання. «Вище життя, життя життя, або духовність, що конкретно споглядається як світло, являється взоруванню в образах цілісності» $[11,115]$.

Там, де панує Боже Слово як Закон, кожен фрагмент дійсності висвічує собою всеохопність небес. А перервність світових явищ постає основою для зосередженості в ній шляхів до нескінченності. Тому кожна «точка розлому» $є$ водночас «точкою виходу» по той бік ілюзій, точкою єднання даності та зворотності, точкою вибору, зрештою. Людству до вподоби запустити ритм своїх сердець посеред штучних горизонтів, які одвічно віддаляються. Такий підхід гарантує, на перший погляд, затишність та чистоту перебування. Однак спокій такої світової конструкції уподібнюється до порожнього закинутого дому, в якому ніколи не буде хаосу, в якому нічого не розіб'ється, бо ніхто не завітає в той дім. Так і ми, проживаючи саморобне життя, не усвідомлюємо, що нас, таких, як ми себе вигадали, насправді не існує. Але вирватися з цього не-існування можливо, збагнувши те, що жодна досконалість дому-світу насправді не варта нічого без Бога та Його законів. А тому неминуче розбиваються стіни такого дому задля того, аби мати змогу побачити Сонце Правди. «Світ є надтріснутим, і причина цього - гріх та зло. Антиномічність долається подвигом віри та любові» $[12,35]$. Всі протилежності нашого саморобного світу можуть розчинитися в світлі Божої благодаті. Однак задля цього людська душа має трудитися та ламати оманливі побудови оманливого світу. Сяйво вічності не проллється в простір гордих сердець, яким здається, що їм нічого не потрібно, окрім їх власної «вічності». А усвідомлення внутрішньої розколеності серця очищує простір зовнішній та виводить на новий рівень сприйняття, за якого світ ідей та ангелів припиняє бути фантастикою, а пізнається як єдино істинний без жодних замінників. Тільки тоді можливо віднайти наше власне призначення в цьому світі. «Те, що наше завдання таке саме величне, як і наше життя, кидає на останнє відблиск нескінченності» $[4,58]$. Життя на землі може увійти в правильне річище тільки тоді, коли усвідомиться міра відповідальності людини перед усім світом, який вона занурила в гріх-оману. Відчуття величності нашого призначення, 3 одного боку, занурює в страх від розуміння наслідків кожного неправильного кроку, але натомість відкриває вимір глибини та краси в кожній миттєвості, що початково є вкоріненою до вічності. 


\section{ЛIТЕРАТУРА}

1. Паршин А.Н., Седых О.М. Конкретная метафизика священника Павла Флоренского // Павел Александрович Флоренский. - М., 2013. - С.7-29.

2. Флоренский Павел, священник. Детям моим. Воспоминания прошлых дней. Генеалогические исследования. - М., 1992. - 560 с.

3. Флоренский П.А. Об одной предпосылке мировоззрения // Флоренский П.А., священник. - Соч. : В 4т. / Т.1. - М., 1994. - С.72-84.

4. Кафка Ф. Ангелы не летают. С 59 / Пер. с нем. Г. Ноткина. - СПб., 2009. - $192 \mathrm{c}$.

5. Флоренский П.А. Пифагоровы числа // Флоренский П.А., священник. Соч. : В 4т. / Т.2 .- М., 1996.

6. Шапошников B.A. Математическая апологетика П.Флоренского // На пути к синтетическому единству европейской культуры. Философскобогословское наследие П.А. Флоренского и современность. - М., 2006. C. 177-196.

7. Флоренский П.А. У водоразделов мысли // Флоренский П.А. - Соч. : B4т. - T.3 (2). - М., 2000. - 623 c.

8. Флоренский П.А. Культурно-историческое место и предпосылки христианского миропонимания // Там же. - С.386-488.

9. Флоренский Павел. Автореферат // Флоренский П.А., священник. Соч. : В 4 т. - T.1. - М., 1994. - 797 c.

10. Иустин Попович. Подвижнические и богословские главы // Собрание творений преподобного Иустина (Поповича). - М., 2004. - С. 84-165.

11. Флоренский П.А. Смысл идеализма // Флоренский П.А. - Соч. : В 4 т. T.3 (2). - M., 2000. - C.68-145.

12. Трубачев А.С. Основные направления творческого наследия священника Павла Флоренского. - М., 2013. - С.29-48.

Василенко Ю.В. Перервність простору світових явищ як можливість повернення до світла вічності.

У статті розкривається перервність усіх процесів та явищ видимого простору і обгрунтовується неможливість «матеріальної нескінченності». Аналіз абсурдності речей світу як замкнених систем доводить істинність Божої нескінченності, світла вічності, до якого необхідно повернутись.

В дослідженні простежується зв'язок між філософськими вимірами П.О.Флоренського та аритмологічним способом осягнення дійсності. Аритмологія як вчення про розривність світових явищ надає обгрунтування неможливості віднайдення шляху до первинної цілісності посеред розколотих самозамкнених уламків дійсності. 3 іншого боку, розкривається виправданість факту наявності в кожній «піднебесній» речі їі унікальної 
сутності, пульсації смислу. У відповідності з цим, світ постає не як «безлика тотальність», а як різнорідність простору, в кожному моменті якого зосереджується внутрішній логос речей, по причині їх первинної вкоріненості в небесній нескінченності. Така антиномічність долається на вищих рівнях діяльності людської душі, на рівні зцілення серця від ілюзій як наслідків надмірної прив'язаності до пошуків Абсолюту посеред порожнечі. Здійснення аналізу абсурдності речей світу як замкнених систем приводить до виявлення істинності Божої нескінченності, світла вічності, до якого необхідно повернутись.

Ключові слова: простір, час, аритмологія, вічність, душа, реальність.

Василенко Ю.В. Прерывность пространства мировых явлений как возможность возвращения к свету вечности.

В статье дается раскрытие прерывности всех процессов и явлений видимого пространства и обосновывается невозможность «материальной бесконечности». В исследовании прослеживается связь между философскими измерениями П.А.Флоренского и аритмологическим способом постижения действительности. Аритмология как учение о разрывности мировых явлений дает обоснование невозможности нахождения пути к первичной целостности между расколотыми самозамкнутыми фрагментами действительности. С другой стороны, раскрывается оправданность факта наличия в каждой поднебесной вещи ее уникальной сущности, пульсации смысла. В соответствии с этим, мир являет собой не «безликую тотальность», а разнородность пространства, в каждом моменте которого сосредоточен внутренний логос вещей, по причине их первичной укорененности в небесной бесконечности. Такая антиномичность устраняется на высших уровнях деятельности человеческой души, на уровне исцеления сердца от иллюзий как последствий излишней привязанности к поискам Абсолюта посреди пустоты. Совершение анализа абсурдности вещей мира как замкнутых систем приводит к выявлению истинности Божьей бесконечности, света вечности, к которому необходимо возвратиться.

Ключевые слова: пространство, время, аритмология, вечность, душа, реальность.

Vasylenko J. Breakability of space of world's phenomena as a possibility for return to the light of eternity.

The article shows the breakability of all processes and phenomena in the visual space and gives realization of the false of «material infinity». In research there is a discovery of connection between philosophical dimension of P.Florensky and the way of arythmological comprehension of reality. Arythmology as a study of breakability of the world's phenomena gives a ground of disability for finding out the way to primary wholeness of the broken self-locked fragments 
of reality. On the other side, there is discovering of justify for the fact of containing the unique essence and pulsation of sense in every thing under the heaven. In according with this fact, the world becomes not as «totality without face», but still as a variety of space, and in it's every moment there is an inner logos of things because of their primary implanting in heaven's endlessness. Such antinomien gets away on the highest level of human soul's activity, on the level of healing the heart from illusions as consequences of superfluous affection to finding out Absolute in the middle of emptiness. It was analyzed that all things of the world as closed systems have no sense. So that we should discover the truth in the infinity of God and return to the light of eternity.

Key words: space, time, arythmology, eternity, soul, reality. 